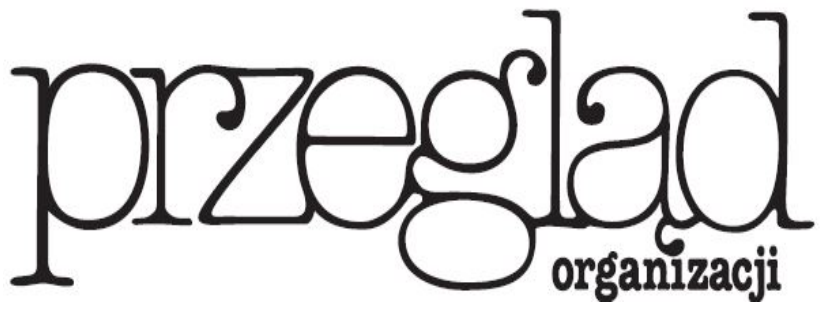

Miesięcznik TNOiK Założył Karol Adamiecki w 1926 r.

\title{
PROJECT GOVERNANCE - ISTOTA, DOTYCHCZASOWE KIERUNKI BADAWCZE I PERSPEKTYWY ROZWOJU
}

https://doi.org/10.33141/po.2019.03.06

\section{Eryk Głodziński}

\section{Wprowadzenie}

B dania naukowe dotyczące działalności projektowej cechuje różnorodność zarówno w zakresie przedmiotu studiów, jak i stosowanych podejść badawczych. Wynika to przede wszystkim, choć nie tylko, ze zjawiska projektyzacji, które można rozumieć jako „nowy megatrend zarządzania, ilustrujący wzrastające znaczenie projektów we wszystkich dziedzinach i na wszystkich poziomach aktywności ludzkiej” (Trocki, 2018, s. 10). Odpowiedzią na rosnące znaczenie projektyzacji jest m.in. znaczący przyrost wiedzy zarządczej. Świadectwem tego zjawiska może być lektura artykułów w najbardziej cenionych czasopismach dotyczących działalności projektowej, m.in.: International Journal of Project Management, Project Management Journal, International Journal of Managing Projects in Business czy International Journal of Information Systems and Project Management.
Przegląd Organizacji, Nr 3 (950), 2019, ss. 32-42 www.przegladorganizacji.pl cTowarzystwo Naukowe Organizacji i Kierownictwa (TNOiK)
Również w Polsce tematyka zarządzania w środowisku projektowym stanowi istotny obszar badań naukowych i prac rozwojowych. Głównymi obszarami zainteresowania są różnorodne problemy związane $\mathrm{z}$ zarządzaniem projektem, programem, portfelem projektów, a od kilku lat również zarządzaniem organizacjami projektowymi (organizational project management) czy project governance. Ostatni $\mathrm{z}$ przytoczonych obszarów wydaje się najmniej rozpoznany. Jednakże ma on duże znaczenie dla działalności gospodarczej, o czym świadczą wyniki badań prowadzonych przede wszystkim w BI Norwegian Business School oraz University of Technology Sydney. Zainteresowanie tym obszarem wykazują również organizacje profesjonalnie zajmujące się projektami, m.in. Project Management Institute (PMI) czy Association of Project Management (APM). 
Należy zauważyć, że w Polsce stosunkowo rzadko podejmowana jest tematyka project governance, w tym jej adaptacja do krajowych uwarunkowań. Przykładem mogą być jedynie opracowania M. Trockiego (2018, s. 9-23) oraz E. Głodzińskiego (2017a, s. 100-106). Dlatego zauważalne są niedostatki w zdefiniowaniu polskojęzycznego słownika pojęciowego czy rozumieniu idei tego konstruktu. Również w praktyce występuje wiele niejasności związanych np. ze stosowaniem tego rozwiązania. Stanowi to istotną lukę badawczą, której chociażby częściowe wypełnienie stało się motywem podjęcia przedmiotowego tematu. W niniejszym artykule sformułowano następujące pytania badawcze:

- (PB1): jakie istotne obszary badawcze i trendy można wyodrębnić w ramach studiów nad project governance?

- (PB2): jakie można wyodrębnić dotychczas w niewielkim stopniu zbadane obszary badawcze project governance?

$\mathrm{Na}$ tej podstawie przyjęto, że głównymi celami artykułu są: przedstawienie istoty przedmiotowego konstruktu, określenie istotnych kierunków badań nad tematyką project governance oraz wskazanie możliwych nowych obszarów eksploracji naukowej. Celem pośrednim artykułu jest propagowanie przedmiotowej wiedzy w Polsce, wskazanie znaczenia systemów governance w tworzeniu wartości projektów, programów, portfela projektów czy organizacji projektowej.

\section{Metodyka badań i zastosowane metody badawcze}

D la zrealizowania przedstawionych celów i znalezienia odpowiedzi na wskazane pytania badawcze w pierwszym kroku scharakteryzowano ogólny sposób rozumienia governance $\mathrm{w}$ środowisku projektowym. Przedstawiono istotę jego projektowania i wykorzystania. Następnie dla określenia obszarów badawczych, kierunków i perspektyw rozwoju przyjęto następującą metodyką:

1. Poszukiwanie metodą parasolowego przeglądu literatury (umbrella review) ${ }^{1}$ tych publikacji, które wykorzystując systematyczną analizę literatury przedmiotu (systematic literature review) ${ }^{2}$ opisują problematykę governance w działalności projektowej. Badania skoncentrowano na analizie baz Scopus oraz Google Scholar do dnia 7.01.2019 roku. Poszukiwano w tytułach publikacji, ich słowach kluczowych i abstraktach fraz: "project”, „governance” i „literature review” lub „literature analysis”, „literature outlook”. Następnie dokonano przeglądu tekstów pod kątem ich zgodności z celami i strategią badawczą niniejszego artykułu. Wybrane publikacje oznaczono indeksem (G1).

2. Uzupełnienie stworzonej listy w pkt. 1 o inne publikacje spełniające przyjęte kryteria, które pochodziły z zasobów bibliograficznych grupy (G1). W dalszej części publikacje te oznaczono indeksem (G2).

3. Dalsze uzupełnienie listy o publikacje niespełniające przyjętych kryteriów, jednakże będące szerokim przeglądem stanu wiedzy. Dobór publikacji nastąpił z wykorzystaniem dwóch alternatywnych kryteriów. Pierwszym była rozpoznawalność autorów. Przyjęto, że powinni to być uznani badacze $\mathrm{z}$ zakresu project governance, a ich publikacje ukazały się w renomowanych czasopismach lub wydawnictwach. Jako uznanych autorów przyjęto badaczy, których publikacje z zakresu analizowanej tematyki uzyskały wysoką liczbę cytowań (na dzień 7.01.2019 r. wg bazy Scopus min. 90, wg bazy Google Scholar min. 100). Kryteria te spełniły publikacje następujących autorów: J.R. Turner, M.P. Abednego, S.O. Ogunlana, R. Muller, S.D. Pryke, E.G. Too, P. Weaver, R. Joslin, W.J. Henisz, R.E. Levitt, W.R. Scott, G.M. Winch, A. Keegan, S.D. Pryke. Drugim kryterium był wkład publikacji oraz pozycja wydawcy w rozwój subdyscypliny zarządzania projektami. W tym przypadku przyjęto, że uznanie środowiska posiadają organizacje profesjonalne zrzeszające teoretyków i praktyków z zakresu zarządzania projektami, w tym Project Management Institute czy Association of Project Management. W przypadku zastosowania obydwu kryteriów założono dodatkowo, że opracowania muszą mieć charakter przeglądowy. Tę grupę publikacji oznaczono indeksem (G3).

4. Przeprowadzenie syntezy wyników badań $\mathrm{z}$ pkt. 1-3 z wykorzystaniem metody narracji (Paré i in., 2015, s. 186), której głównym celem było wskazanie istotnych obszarów eksploracji tematyki project governance.

5. Porównanie wyników syntezy (pkt 4) z rezultatami obserwacji nieuczestniczącej autora niniejszego artykułu. Prowadzona była ona w latach 2017-2018 w ramach działalności eksperckiej i doradczej w organizacjach projektowych (dwóch dużych przedsiębiorstwach budowlanych oraz jednym średniej wielkości przedsiębiorstwie informatycznym) celem wskazania luk badawczych między wynikami obserwacji nieuczestniczącej a badaniami literaturowymi.

6. Podsumowanie wyników badań i wskazanie ich ograniczeń w zakresie szerszej interpretacji na całą populację. Zastosowanie parasolowego przeglądu literatury, tj. wyników $\mathrm{z}$ przeprowadzonych przez innych autorów systematycznych analiz literatury przedmiotu z zakresu project governance, wynikało $\mathrm{z}$ potrzeby wskazania złożoności podejmowanej problematyki oraz określenia występujących luk badawczych. Metoda ta ma zastosowania w sytuacji, gdy obszar badawczy jest silnie eksplorowany, przez co zasadne staje się przedstawienie w jednym miejscu syntezy wyników tych studiów ${ }^{3}$. Tego typu metoda badawcza dotychczas znalazła zastosowanie głównie w naukach medycznych (Aromataris i in., 2015, s. 132-140), gdzie występuje bardzo obszerny materiał badawczy. W przypadku nauk o zarządzaniu i jakości baza danych jest zazwyczaj znacznie mniejsza, dlatego podjęto decyzję o uzupełnieniu publikacji wykorzystujących systematyczną analizę literatury przedmiotu (G1 i G2) o inne opracowania (G3).

Przyjęte metody badawcze umożliwiają również sprawdzenie, który z ważnych, zdaniem autora niniejszego artykułu, aspektów project governance został pominięty w wynikach systematycznych analiz literatury przedmiotu ${ }^{4}$. 


\section{Project governance a projektyzacja organizacji}

W prowadzenie project governance powinno stanowić jeden $\mathrm{z}$ istotnych etapów projektyzacji organizacji. Sprawne funkcjonowanie tego systemu to warunek konieczny osiągnięcia pełnej dojrzałości projektowej podmiotu. Według M. Trockiego, wprowadzanie project governance następuje na najwyższym czwartym poziomie projektyzacji (2018, s. 14). Uwzględniając istotną rolę tego systemu $\mathrm{w}$ doskonaleniu organizacji oraz niewielki stopień popularyzacji w polskojęzycznej literaturze przedmiotu, konieczne jest we wstępnej części rozważań wskazanie jego tła i znaczenia.

Źródeł początkowej wiedzy dla project governance poszukiwano $\mathrm{w}$ dorobku corporate governance, najczęściej tłumaczonego na język polski jako ład korporacyjny lub ład organizacyjny ${ }^{5}$. Według OECD $(2015$, s. 9), governance to ukształtowane relacje między zarządzającymi przedsiębiorstwem, jego zarządem, udziałowcami oraz innymi interesariuszami. Dotyczą one sposobów i zakresu określenia celów działalności organizacji, organizacji procesu monitorowania i kontroli realizacji, $\mathrm{w}$ tym definiowania mierników pomiarowych. Tworzony w ten sposób porządek (ład) powinien określać również zasady wyboru menedżerów czy stymulowania transparentności i uczciwości ich pracy na rzecz podmiotu, co jest konsekwencją istnienia relacji pryncypał (mocodawca, często właściciel) vs. agent (pełnomocnik, zarządzający) (Freeman, Reed, 1983, s. 88-106; Shleifer, Vishny, 1997, s. 737; Tricker, Tricker, 2015).

Wyjaśnienia tych relacji dostarcza teoria agencji przedsiębiorstwa. W praktyce corporate governance obejmuje stworzenie w organizacji takich rozwiązań zarządczo-kontrolno-nadzorczych, aby menedżerowie koncentrowali się „na utrzymaniu zaufania interesariuszy (do podmiotu - przypis aut.) w celu zapewnienia przedsiębiorstwu trwałego, zrównoważonego rozwoju” (Samborski, 2012, s. 17). Działania takie są niezbędne, aby zabezpieczyć podmiot przed ewentualnym wystąpieniem negatywnych działań, np. przedkładania przez menedżera interesu własnego nad interesem zarządzanego podmiotu. Praktyka przedsiębiorstw w tym obszarze jest kształtowana przez różnego rodzaju uwarunkowania, w tym obowiązujące prawo, system polityczny, normy społeczne, kulturę organizacyjną czy strukturę własności (Aluchna, Postuła, 2017, s. 148-149).

$\mathrm{Z}$ bogatego dorobku corporate governance korzystają praktycy i naukowcy profesjonalnie zajmujący się zarządzaniem projektami. Stworzyli oni nazwę project governance, która została szeroko rozpropagowana $\mathrm{w}$ anglojęzycznej literaturze przedmiotu (Turner, Müller, 2003, s. 1-8; Shenhar, 2001, s. 239-271). Wskazuje się m.in., że konstrukt ten jest architekturą i sposobem, w jaki pojedyncze projekty, ich grupy (np. programy czy portfele) oraz cała działalność projektowa organizacji są kierowane i kontrolowane, a menedżerowie są pociągani do odpowiedzialności za rezultaty tej działalności. W ten sposób wspomaga się projekt w osiąganiu jego celów (sukcesu). Wdrożenie systemu governance prowadzi do zwiększenia wartości działań projektowych i ich produktu, co jest istotne $\mathrm{z}$ perspektywy wszystkich interesariuszy - wewnętrznych i zewnętrznych, w tym również organizacji projektowej.

Reasumując ideę governance w środowisku projektowym, można wskazać, że występuje tu bardzo wiele złożonych obszarów problemowych - aspekty: twarde vs. miękkie, zewnętrze vs. zewnętrzne względem projektu, kontrola vs. zaufanie, podejście funkcjonalne vs. procesowe czy modelowe itp. Stanowi to w pewnym stopniu wytłumaczenie wielości i wielowątkowości prowadzonych badań. Duże zainteresowanie tym obszarem wynika również ze zgłaszanych przez interesariuszy potrzeb o charakterze wspomagająco-kontrolnym względem zespołów projektowych.

\section{Przegląd systematycznych analiz literatury przedmiotu}

7 astosowanie przedstawionej metodyki badań umożL liwiło wyodrębnienie pozycji, które odzwierciedlają główne trendy w zakresie prowadzonych badań na temat project governance. Wyniki badań zestawiono według kryteriów wyodrębnionych grup, a następnie chronologiczności, co umożliwia podjęcie dyskusji nad rozwojem wiedzy w odniesieniu do analizowanego obszaru (tab. 1).

$\mathrm{Na}$ podstawie przyjętych kryteriów wyodrębniono siedem publikacji zaliczonych do grupy G1. Zostały one $\mathrm{w}$ większości opublikowane $\mathrm{w}$ renomowanych czasopismach anglojęzycznych. Istotny wkład w stan wiedzy wniósł specjalny numer czasopisma International Journal of Project Management (Vol. 32, No. 8). Do grupy G2 przypisano dwa teksty naukowe. Grupa G3 składa się z sześciu opracowań (tab. 1).

Liczba wyodrębnionych systematycznych przeglądów literatury przedmiotu (G1) pozwala stwierdzić, że na temat project governance powstało wiele opracowań i zestawień. Potwierdzają to dane zbiorcze odnoszące się do liczby opublikowanych artykułów w renomowanych czasopismach. Wskazują one, że opracowania na temat project governance zaczęly powstawać po 1999 roku. Znaczny wzrost liczby publikacji nastąił w 2005 roku (Biesenthal, Wilden, 2014, s. 1295). Oznacza to, że konstrukt ten jest - szczególnie w ostatnich latach - popularnym tematem badawczym. Pierwsze znaczące opracowania (kryterium rozpoznawalności - cytowalność) na ten temat powstały w roku 2001 (Winch, 2001, s. 799-808). Na tej podstawie można stwierdzić, że pod względem ilościowym wiedza dotycząca project governance jest obszerna. Wzrost zainteresowania tym tematem wśród badaczy $\mathrm{z}$ pewnością wynika z rosnącej złożoności projektów, towarzyszących im uwarunkowań ryzyka i niepewności czy coraz powszechniejszego zjawiska projektyzacji. Wymuszają one zmiany w sposobie pracy, rozwoju kariery, stabilności zatrudnienia (Juchniewicz, 2018, s. 57).

$\mathrm{Na}$ podstawie zgromadzonego materiału trudno wysunąć wniosek o dojrzałości analizowanego obszaru wiedzy. "Młodość" analizowanej problematyki i częste podejmowanie tematów odnoszących się do jej fundamentów (np. sposób rozumienia project governance - w opracowaniach 


\begin{tabular}{|c|c|c|c|}
\hline Publikacja & $\begin{array}{l}\text { Główne tezy, } \\
\text { pytania badawcze, } \\
\text { cele publikacji }\end{array}$ & Kluczowe wyniki badań & $\begin{array}{c}\text { Oznaczenie } \\
\text { grupy } \\
\text { i numeru } \\
\text { publikacji }\end{array}$ \\
\hline $\begin{array}{l}\text { (Ahola, } \\
\text { Ruuska, Artto, } \\
\text { Kujala, 2014, } \\
\text { s. 1321-1332) }\end{array}$ & $\begin{array}{l}\text { - jak definiowany jest } \\
\text { project governance? } \\
\text { - jaka jest geneza } \\
\text { powstawania project } \\
\text { governance? } \\
\text { - w jakim zakresie project } \\
\text { governance wykorzystuje } \\
\text { wiedzę z zakresu ogólnej } \\
\text { koncepcji governance? }\end{array}$ & $\begin{array}{l}\text { Występują dwa główne nurty badań w ramach project governance: a) tworzenie } \\
\text { podstaw zależności między projektem a klientem zewnętrznym (project gover- } \\
\text { nance as external to any specific project), b) tworzenie podstaw zależności między } \\
\text { projektem a przedsiębiorstwem projektowym (project governance as internal to } \\
\text { a specific project). Początkowe badania w zakresie project governance koncentro- } \\
\text { wały się głównie wokół wiedzy i problemów związanych z zarządzaniem projek- } \\
\text { tami. Obecnie obejmują również programy czy portfele projektów. Początkowo } \\
\text { badania odnosiły się do teorii kosztów transakcyjnych czy agencyjnej teorii } \\
\text { przedsiębiorstwa. Obecnie coraz częściej odnoszą się do aspektów ograniczonej } \\
\text { racjonalności, zachowania osób zaangażowanych w projekcie, relacji występują- } \\
\text { cych w sieciach. }\end{array}$ & G1.1 \\
\hline $\begin{array}{l}\text { (Bekker, 2014, } \\
\text { s. 22-32) }\end{array}$ & $\begin{array}{l}\text { - określenie szkół myślenia } \\
\text { (podejść badawczych) } \\
\text { w studiach na temat } \\
\text { project governance } \\
\text { - określenie dalszych } \\
\text { obszarów badawczych } \\
\text { w zakresie project } \\
\text { governance }\end{array}$ & $\begin{array}{l}\text { Istnieją trzy funkcjonalne poziomy zarządzania: a) operacyjny (operacjonalizacja } \\
\text { codziennej działalności, kontrola realizacji zadań), b) strategiczny (zapewnienie } \\
\text { realizacji strategii organizacji matki, przywództwo, wywiązywanie się z zapisów } \\
\text { kontraktowych, relacje z interesariuszami), c) instytucjonalny (rozpatrywanie } \\
\text { aspektów: socjologicznych, politycznych, środowiskowych, w połączeniu z syste- } \\
\text { mem zarządzania organizacją). W zależności od specyfiki zróżnicowanych orga- } \\
\text { nizacji postuluje się uwzględniać odmienne podejścia badawcze, tj. perspektywy: } \\
\text { a) indywidualnej organizacji (single firm), gdzie nie są analizowane interakcje } \\
\text { z podmiotami zewnętrznymi (zleceniodawcami), badane jest wnętrze projektu } \\
\text { jako organizacji tymczasowej - studia odnoszące się do poziomów operacyjnego } \\
\text { i strategicznego, } \\
\text { b) międzyorganizacyjny (multi-firm), gdzie występują silne interakcje międzyor- } \\
\text { ganizacyjne a relacje w dużej części są definiowane zapisami umownymi (np. umo- } \\
\text { wa projektowa), co wymaga ścisłego nadzoru nad: administrowaniem umową, } \\
\text { utrzymywaniem relacji w sieci, zarządzaniem ryzykiem, kontrolą działań w całym } \\
\text { cyklu życia projektu, komunikacją wewnątrz zespołu projektowego; w ramach tej } \\
\text { perspektywy kluczową rolę odgrywają poziomy operacyjny i strategiczny, } \\
\text { c) dużego kapitału (large capital), tj. megaprojektów tworzących organizację tym- } \\
\text { czasową, która sama tworzy reguły funkcjonowania i nadzoru, dlatego główna } \\
\text { uwaga skierowana jest na poziomy strategiczny i instytucjonalny. } \\
\text { Nie można wskazać jednego standardu czy sposobu myślenia, który opisuje wła- } \\
\text { ściwy system ładu korporacyjnego (corporate governance) z jego podsystemami } \\
\text { nadzoru. Problematyka ta jest złożona i wymaga dalszych badań. }\end{array}$ & G1.2 \\
\hline $\begin{array}{l}\text { (Biesenthal, } \\
\text { Wilden, 2014, } \\
\text { s. 1291-1308) }\end{array}$ & $\begin{array}{l}\text { - określenie głównych } \\
\text { obszarów badań nad } \\
\text { problematyką project } \\
\text { governance } \\
\text { - porównanie badań } \\
\text { nad project governance } \\
\text { publikowanych } \\
\text { w czasopismach } \\
\text { z zakresu zarządzania } \\
\text { oraz dedykowanych } \\
\text { zarządzaniu projektami } \\
\text { - określenie dalszych } \\
\text { obszarów badawczych } \\
\text { łączących teorię } \\
\text { governance z project } \\
\text { governance }\end{array}$ & $\begin{array}{l}\text { Ze względu na różnorodność podejść stosowanych w badaniach project governan- } \\
\text { ce trudno jest przyjąć jego jednolitą definicję. Konstrukt ten wykorzystuje dorobek } \\
\text { przede wszystkim sześciu teorii ekonomicznych lub organizacji i zarządzania: } \\
\text { agencji (agency), kosztów transakcyjnych (transaction cost), interesariuszy (sta- } \\
\text { kekholder), właścicielskiej (shareholder), podwładności (stewardship), zasobowej } \\
\text { (resource dependence). Dodatkowo aspekty governance są często analizowane } \\
\text { w kontekście: zarządzania zmianą, realizacji strategii (projektu vs. organizacji } \\
\text { projektowej lub inwestora) czy zarządzania dokonaniami (performance). Project } \\
\text { governance rozpatrywać należy na trzech poziomach: projektu, biura projektowe- } \\
\text { go (łącznik między projektem a organizacją projektową) oraz organizacji projekto- } \\
\text { wej. Najczęściej analizowanym segmentem w kontekście governance są podmioty } \\
\text { budowlane. W przyszłych badaniach nad governance należy w większym stopniu } \\
\text { uwzględnić kontekst zwinności organizacji. }\end{array}$ & G1.3 \\
\hline $\begin{array}{l}\text { (Müller, } \\
\text { Pemsel, } \\
\text { Shao, 2014, } \\
\text { s. 1309-1320) }\end{array}$ & $\begin{array}{l}\text { - identyfikacja } \\
\text { organizacyjnych } \\
\text { inicjatorów (enablers) } \\
\text { governance of project } \\
\text { based-organization } \\
\text { i kreowania mentalności } \\
\text { nadzorczo-kontrolnych } \\
\text { (governmentality) }\end{array}$ & $\begin{array}{l}\text { Zauważono następujące zależności: } \\
\text { a) im wyższy poziom dojrzałości projektowej i stosowanego ładu organizacyjnego, } \\
\text { tym istotniejszą rolę w systemie governance odgrywają aspekty miękkie zarządza- } \\
\text { nia np. kultura organizacyjna, otwartość, zaufanie, wyznawane wartości, } \\
\text { b) im niższy poziom dojrzałości projektowej i stosowanego ładu organizacyjnego, } \\
\text { tym większą rolę w systemie governance odgrywają elementy twarde, np. struktu- } \\
\text { ry, procedury, wykorzystywane metody i instrumenty wspomagające zarządzanie, } \\
\text { c) elastyczność jest kluczową cechą governance, jej rola może być zróżnicowana } \\
\text { ze względu na dojrzałość projektową organizacji matki, przy niższych poziomach } \\
\text { elastyczność dotyczy wyboru metod czy realizowanych procesów, przy wyższych } \\
\text { poziomach odnosi się do sposobów myślenia i działania. }\end{array}$ & G1.4 \\
\hline
\end{tabular}




\begin{tabular}{|c|c|c|c|}
\hline Publikacja & $\begin{array}{l}\text { Główne tezy, } \\
\text { pytania badawcze, } \\
\text { cele publikacji }\end{array}$ & Kluczowe wyniki badań & $\begin{array}{l}\text { Oznaczenie } \\
\text { grupy } \\
\text { i numeru } \\
\text { publikacji }\end{array}$ \\
\hline $\begin{array}{l}\text { (Too, Weaver, } \\
2014 \text {, } \\
\text { s. } 1382-1394 \text { ) }\end{array}$ & $\begin{array}{l}\text { - jakie są różnice } \\
\text { między zarządzaniem } \\
\text { (management) } \\
\text { a rząazeniem przez } \\
\text { nadzór i kontrolę } \\
\text { (governance)? } \\
\text { - w jaki sposób P3 } \\
\text { governance może } \\
\text { przyczynić się do } \\
\text { osiągania lepszych } \\
\text { rezultatów, w tym } \\
\text { wzrostu wartości? }\end{array}$ & $\begin{array}{l}\text { Zarządzanie projektem (project management) wpływa bezpośrednio na osiągane } \\
\text { przez P3 wyniki, w tym ich sukces. Project governance obejmuje natomiast przede } \\
\text { wszystkim określenie celów i kryteriów sukcesu, zapewnienie dostępności zasobów } \\
\text { i kontrolę efektywności ich wykorzystania. Funkcjami, które spełnia project gover- } \\
\text { nance powinny być właściwy dobór projektu do portfela oraz strategiczne dopaso- } \\
\text { wanie } P 3 \text { do strategii organizacji matki. Głównymi czynnikami sukcesu projektu } \\
\text { z perspektywy governance są: odpowiednie zarządzanie portfelem projektów, wspar- } \\
\text { cie projektu przez sponsora (podmiot odpowiedzialny za cały cykl życia projektu ze } \\
\text { strony klienta), wsparcie ze strony biura projektów, właściwe zarządzanie projektem } \\
\text { / programem. }\end{array}$ & G1.5 \\
\hline $\begin{array}{l}\text { (Lappi, } \\
\text { Karvonen, } \\
\text { Lwakatare, } \\
\text { Aaltonen, } \\
\text { Kuvaja, 2018, } \\
\text { s. } 39-63 \text { ) }\end{array}$ & $\begin{array}{l}\text { zrozumienie koncepcji } \\
\text { governance w środowisku } \\
\text { zwinnego zarzadzania, } \\
\text { zidentyfikować } \\
\text { i usystematyzować } \\
\text { wykorzystywane praktyki }\end{array}$ & $\begin{array}{l}\text { Występują różnice między szczegółowymi rozwiązaniami governance w przypadku } \\
\text { wykorzystania tradycyjnych i zwinnych modeli zarządzania projektem. Wciąż jest } \\
\text { zbyt mało badań na temat governance w ramach podejścia zwinnego. W opracowa- } \\
\text { niu skoncentrowano się na identyfikacji głównych praktyk wspomagających imple- } \\
\text { mentację i eksploatację tego typu systemów. }\end{array}$ & G1.6 \\
\hline $\begin{array}{l}\text { (Derakhshan, } \\
\text { Turner, } \\
\text { Mancini, 2019, } \\
\text { s. 98-116) }\end{array}$ & $\begin{array}{l}\text { - określenie głównych } \\
\text { obszarów badawczych } \\
\text { w zakresie project } \\
\text { governance }\end{array}$ & $\begin{array}{l}\text { W wyjaśnianiu problematyki project governance dominuje pięć teorii: agencji (agen- } \\
\text { cy), kosztów transakcyjnych (transaction cost), podwładności (stewardship), zaso- } \\
\text { bowej (resource dependence), interesariuszy (stakekholder). Dzięki ich zastosowaniu } \\
\text { wskazuje się trzy zasadnicze obszary badawcze: } \\
\text { a) P3 governance jako czynnik sukcesu projektu, system zapewniający wzrost warto- } \\
\text { ści przez pomiar dokonań i doskonalenie efektywności, } \\
\text { b) znaczenie etyki, transparentności oraz właściwego zdefiniowania ról w ra- } \\
\text { mach P3, } \\
\text { c) identyfikacja roli interesariuszy (wewnętrznych i zewnętrznych) jako podmiotów } \\
\text { decyzyjnych i kreatorów wartości dodanej } P 3 \text {. } \\
\text { W warstwie metodologicznej w badaniach najczęściej wykorzystuje się: podejście } \\
\text { indukcyjne, metody studium przypadku i badania ankietowe. Dostępne badania nad } \\
\text { P3 governance dotyczą głównie poziomu projektu i organizacji projektowej. }\end{array}$ & G1.7 \\
\hline $\begin{array}{l}\text { (Ahola, } \\
\text { Davies, 2012, } \\
\text { s. 661-679) }\end{array}$ & $\begin{array}{l}\text { określenie obszarów, } \\
\text { które są kluczowe } \\
\text { z perspektywy teorii } \\
\text { zarządzania dużym, } \\
\text { złożonym projektem }\end{array}$ & $\begin{array}{l}\text { Są cztery kluczowe obszary badawcze eksplorowane w ramach zarządzania dużym, } \\
\text { złożonym projektem. Są to: sprawowanie nadzoru i kontroli (governance), analiza } \\
\text { warunków ryzyka i niepewności, doskonalenie realizowanych procesów (dojrzałość } \\
\text { projektowa), zarządzanie zespołem projektowym. Najbardziej niedocenianym ob- } \\
\text { szarem jest project governance. }\end{array}$ & $\mathrm{G} 2.1$ \\
\hline $\begin{array}{l}\text { (Musawir, } \\
\text { Abd-Karim, } \\
\text { Danuri, 2016, } \\
\text { s. 1-11) }\end{array}$ & $\begin{array}{l}\text { - jak definiowany jest } \\
\text { project governance } \\
\text { w literaturze przedmiotu? } \\
\text { - w jaki sposób project } \\
\text { governance wspomaga } \\
\text { strategię organizacji? }\end{array}$ & $\begin{array}{l}\text { Istnieją cztery główne obszary aplikacyjne governance w środowisku projektowym, } \\
\text { tj. obejmujące: organizację projektową, portfel projektów, program, projekt. Okre- } \\
\text { ślono, że w każdym z przytoczonych przypadków można traktować governance jako: } \\
\text { architekturę działania (framework), zbiór realizowanych funkcji (functions) lub pro- } \\
\text { ces (process), które powinny prowadzić do osiągnięcia strategii organizacji i celów } \\
\text { operacyjnych. Przedstawione cztery główne obszary aplikacyjne stanowią elementy } \\
\text { strukturalne ładu korporacyjnego (corporate governance). Governance powinno } \\
\text { obejmować cały cykl życia projektu. Jego celem jest wspomaganie osiągania korzyści } \\
\text { (sukcesu) projektu. }\end{array}$ & $\mathrm{G} 2.2$ \\
\hline $\begin{array}{l}\text { (APM, 2011; } \\
\text { APM, 2012, } \\
\text { s. 8-9) }\end{array}$ & $\begin{array}{l}\text { pomoc } \\
\text { w ustrukturyzowaniu } \\
\text { sposobu myślenia } \\
\text { i działania w wybranych } \\
\text { obszarach, w tym } \\
\text { w zakresie governance }\end{array}$ & $\begin{array}{l}\text { Systemy nadzoru (governance) nad projektem, programem oraz portfelem projek- } \\
\text { tów są integralną częścią ładu korporacyjnego organizacji (corporate governance). } \\
\text { Umożliwiają nie tylko zapewnienie wewnętrznej kontroli, ale również dostarczają } \\
\text { jego interesariuszom wiarygodnej informacji o podmiocie. } \\
\text { Występuje pięć głównych komponentów, na które szczególnie należy uważać przy } \\
\text { budowie i eksploatacji systemów governance: a) wybór akwirowanych projektów } \\
\text { (portfolio direction), b) sponsorowanie projektu (project sponsorship), tj. wspomaga- } \\
\text { nie go przez sponsorów zewnętrznych (przedstawicieli klienta) oraz wewnętrznych } \\
\text { (decydentów organizacji projektowej), c) zarządzanie możliwościami realizacji pro- } \\
\text { jektów (project management capability), d) zamknięcie i raportowanie (closure and } \\
\text { reporting). } \\
\text { Właściwy project governance cechują: określona metodyka nadzoru, ewaluacji i ko- } \\
\text { munikowania wyników, podział i świadomość odpowiedzialności, adekwatność } \\
\text { i znajomość mierników sterująco-kontrolnych, właściwy poziom delegowania } \\
\text { uprawnień i możliwość podejmowania decyzji, przekonanie o wsparciu ze strony } \\
\text { organizacji nadzorującej, właściwe zaangażowanie interesariuszy, przekonanie, że } \\
\text { zarządzanie powinno kreować wartość dodaną P3 i organizacji projektowej. }\end{array}$ & G3.1 \\
\hline
\end{tabular}




\begin{tabular}{|c|c|c|c|}
\hline Publikacja & $\begin{array}{l}\text { Główne tezy, } \\
\text { pytania badawcze, } \\
\text { cele publikacji }\end{array}$ & Kluczowe wyniki badań & $\begin{array}{l}\text { Oznaczenie } \\
\text { grupy } \\
\text { i numeru } \\
\text { publikacji }\end{array}$ \\
\hline $\begin{array}{l}\text { (Müller, 2012, } \\
\text { s. 297-320) }\end{array}$ & $\begin{array}{l}\text { - określenie granic project } \\
\text { governance i kluczowych } \\
\text { wyzwań przed którymi } \\
\text { stoją badacze }\end{array}$ & $\begin{array}{l}\text { Project governance powinien być rozpatrywany przede wszystkim z perspektywy: } \\
\text { ekonomicznej (teoria kosztów transakcyjnych), informacyjnej (teoria agencji) oraz } \\
\text { organizacyjnej (kształtowanie proporcji między zaufaniem a kontrolą). } \\
\text { Kluczową rolę w project governance odgrywają: zarząd organizacji projektowej, ko- } \\
\text { mitet sterujący oraz sponsor (w znaczeniu podejścia mocodawca vs pełnomocnik), } \\
\text { biuro projektów, kierownik programu oraz portfela projektów. } \\
\text { Występują dwa typy orientacji w ramach problematyki governance, tj. na udzia- } \\
\text { łowców (shareholders) oraz wszystkich interesariuszy (stakeholders). Można } \\
\text { wyodrębnić dwa podejścia do kontroli, tj. analizujące dokonania (performance) } \\
\text { oraz zachowania (bahavior). W pierwszym przypadku mocodawca kontroluje je- } \\
\text { dynie rezultaty działalności, w drugim wpływa na jego postawy w trakcie procesu } \\
\text { zarządzania. } \\
\text { Wciąż istnieje wiele znaków zapytania, dlatego niezbędne są dalsze badania doty- } \\
\text { czące project governance. }\end{array}$ & G3.2 \\
\hline $\begin{array}{l}\text { (Turner, 2008, } \\
\text { s. 311-390) }\end{array}$ & $\begin{array}{l}\text { - wskazanie } \\
\text { sposobów i narzędzi } \\
\text { administrowania } \\
\text { organizacją projektową } \\
\text { w nowoczesny sposób }\end{array}$ & $\begin{array}{l}\text { Governance powinno być rozpatrywane w czterech podstawowych kontekstach: za- } \\
\text { rządzanie projektem, zarządzania programem i portfelem projektów, rozszerzania } \\
\text { zdolności organizacyjnych, tworzenia ładu organizacji projektowej. } \\
\text { W zakresie wspomagania projektu istotnym jest badanie relacji między podmiotami } \\
\text { zgodnie z teorią agencji, w szczególności między mocodawcą a pełnomocnikiem. } \\
\text { W ramach wspomagania programu czy portfela istotnym jest analiza znaczenia } \\
\text { i roli biura projektowego (PMO). } \\
\text { W zakresie rozszerzania zdolności organizacyjnych niezbędnym jest projektyzacja } \\
\text { funkcjonowania i dążenie do osiągnięcia wyższego poziomu dojrzałości projektowej. } \\
\text { W ramach tworzenia ładu organizacyjnego ważnym są narzędzia kontrolne, do } \\
\text { których należą przede wszystkim audyt. }\end{array}$ & G3.3 \\
\hline (PMI, 2016) & $\begin{array}{l}\text { - przedstawienie } \\
\text { najważniejszych } \\
\text { praktycznych aspektów } \\
\text { implementacji } \\
\text { governance w środowisku } \\
\text { projektowym }\end{array}$ & $\begin{array}{l}\text { Występują cztery podstawowe obszary aplikacji governance w środowisku projekto- } \\
\text { wym, tj. odnoszące się do: a) organizacji projektowej jako całości (gdzie dąży się do } \\
\text { implementacji governance na potrzeby osiągania celów strategicznych podmiotu), } \\
\text { b) portfela projektów, c) programu, d) projektu. W wyniku zebranych doświadczeń } \\
\text { praktycznych w każdym z wymienionych obszarów aplikacyjnych przedstawiono } \\
\text { wytyczne dotyczące definiowania ról i zakresów odpowiedzialności, domeny } \\
\text { działania, realizowanych funkcji oraz wykonywanych procesów. W opracowaniu } \\
\text { zdefiniowano metodykę wdrażania rozwiązań governance. }\end{array}$ & G3.4 \\
\hline $\begin{array}{l}\text { (Müller i in., } \\
2017 \text { ) }\end{array}$ & $\begin{array}{l}\text { - zdefiniowanie } \\
\text { kluczowych } \\
\text { komponentów } \\
\text { governance } \\
\text { i mentalności } \\
\text { nadzorczo-kontrolnej } \\
\text { (governmentality) } \\
\text { w ramach działalności } \\
\text { projektowej, } \\
\text { i powiązanie ich } \\
\text { - z ladem organizacyjnym } \\
\text { (corporate governance) }\end{array}$ & $\begin{array}{l}\text { System governance obejmuje całość funkcjonowania organizacji projektowej, } \\
\text { w tym nadzór nad wybranymi projektami, programami, portfelami oraz kreowanie } \\
\text { postaw niezbędnych dla spełnienia funkcji governance. } \\
\text { Można zdefiniować cztery zasady, które wspomaga poprawnie funkcjonujący sys- } \\
\text { tem governance. Są to: } \\
\text { a) transparentność działania wobec interesariuszy (transparency), } \\
\text { b) jednoznaczność podziału zadań i odpowiedzialności - właściwe zdefiniowanie } \\
\text { ról (accountability), } \\
\text { c) odpowiedzialność za sposób działania, postępowanie zgodnie z przyjętymi stan- } \\
\text { dardami (responsibility), } \\
\text { d) uczciwość w działaniu - aspekty mornalno-etyczne (fairness). } \\
\text { Istnieją cztery poziomy nadzoru i kontroli: } \\
\text { a) lad korporacyjny (corporate governance), który definiuje cele całego podmiotu } \\
\text { oraz obowiązujące w nim ogólne reguły funkcjonowania, } \\
\text { b) zarządcza działalność projektowa (board-level governance of projects, governance } \\
\text { of PBO), który definiuje reguły prowadzenia działalności projektowej i jej wspoma- } \\
\text { gania m.in. przez PMO, określa ogólne cele zarządzania programami/projektami } \\
\text { w organizacji, } \\
\text { c) portfelowej działalności projektowej (governance of projects), który obejmuje } \\
\text { dobór projektów do portfela organizacji, nadzór nad poprawnością wykorzystania } \\
\text { i doskonalenie mierników oraz metod wspomagających zarządzanie, jak również } \\
\text { doskonalenie systemu raportowania w zakresie projektów, } \\
\text { d) operacyjnej działalności projektowej (project governance), który odpowiada za } \\
\text { określanie celów projektów, dobór niezbędnych zasobów oraz kontrolę dokonań. } \\
\text { Istnieją cztery modele nadzoru. Wynikają one z przyjętych orientacji zarządzania } \\
\text { (interesariusz vs właściciel oraz kontrola wyników vs zachowań): a) elastyczny } \\
\text { ekonomista (flexible economist), b) wszechstronny artysta (versatile artist), c) kon- } \\
\text { formista (conformist), d) zwinny pragmatyk (agile pragmatist). } \\
\text { W zależności od przyjętego modelu relacje między aktorami są determinowane } \\
\text { przez zakres zaufania oraz poziom sprawowanej kontroli. }\end{array}$ & G3.5 \\
\hline
\end{tabular}




\begin{tabular}{|c|c|c|c|}
\hline Publikacja & $\begin{array}{l}\text { Główne tezy, } \\
\text { pytania badawcze, } \\
\text { cele publikacji }\end{array}$ & Kluczowe wyniki badań & $\begin{array}{l}\text { Oznaczenie } \\
\text { grupy } \\
\text { i numeru } \\
\text { publikacji }\end{array}$ \\
\hline $\begin{array}{l}\text { (Turner, } \\
\text { Müller, 2017, } \\
\text { s. 75-91) }\end{array}$ & $\begin{array}{l}\text { czy governance może } \\
\text { odnosić się jedynie do } \\
\text { pojedynczego projektu, } \\
\text { czy również jego sieci }\end{array}$ & $\begin{array}{l}\text { Należy badać rozwiązania governance co najmniej na następujących poziomach: } \\
\text { inwestor vs projekt, przedsiębiorstwo projektowe vs. projekt, przedsiębiorstwo } \\
\text { projektowe vs zleceniodawca, wewnątrz projektu, w ramach sieci projektu. Analiza } \\
\text { zależności powinna następować z uwzględnieniem postrzegania projektu jako orga- } \\
\text { nizacji tymczasowej, która wchodzi w interakcje z innymi organizacjami, tj.: inwe- } \\
\text { storem, portfelem projektów inwestora, przedsiębiorstwem projektowym, portfelem } \\
\text { projektów przedsiębiorstwa projektowego, innymi organizacjami będącymi częścią } \\
\text { sieci projektu. } \\
\text { Project governance jest częścią strukturalną zarządzania przedsiębiorstwem } \\
\text { projektowym. }\end{array}$ & G3.6 \\
\hline
\end{tabular}

Źródto: opracowanie wtasne

G1.1, G1.2, G1.3, G2.2) sugerują początki fazy rozwoju. Jej przejawem są niejednorodność interpretacyjna, w niewielkim stopniu ugruntowana wiedza czy brak własnych teorii (patrz analizy w opracowaniach G1.3, G3.2) i korzystanie $\mathrm{z}$ ujęć teoretycznych wypracowanych $\mathrm{w}$ innych obszarach nauk o zarządzaniu lub ekonomii, np. corporate governance, teorie przedsiębiorstwa. Nie ulega jednak wątpliwości, że w gospodarce występuje duże zapotrzebowanie na nowe rozwiązania wspomagające zarządzanie. To ono stymuluje rozwój konstruktu governance w środowisku projektowym, którego kierunki zostaną szerzej omówione w dalszej części artykułu.

\section{Dyskusja wyników analizy systematycznych przeglądów literatury przedmiotu}

W wyniku przeprowadzonej analizy wyodrębniono kilka stosunkowo często podejmowanych przez naukowców problemów badawczych.

Przede wszystkim należy zauważyć liczne próby porównywania między sobą różnorodnych definicji project governance (G1.1; G2.2; G3.1; G3.4; G3.3; G3.5). Wskazywano, że jest to konstrukt, który można rozumieć bardzo wąsko lub szeroko. W pierwszym przypadku odnosi się do pojedynczego projektu. W wymiarze bardziej ogólnym utożsamia się go z programem czy portfelem projektu, co jest wyrazem przekonania, że governance powinien być realizowany na różnych poziomach zarządzania (G1.2). W tym przypadku należałoby jednak używać innego nazewnictwa, tj. program governance, portfolio governance / governance of projects lub ogólnie $P 3^{6}$ governance. Odrębnym poziomem zastosowania tego konstruktu jest organizacja projektowa, gdzie właściwe jest stosowanie określenia governance of project-based organization (Turner, 2009, s. 367-389), co pozwala na odnoszenie tego konstruktu do omówionych czterech poziomów i nazywanie ich $P 4$ governance. Na różnorodność definicyjną wskazał podczas wykładu wprowadzającego odbywającej się w Lizbonie International Conference on Project MANagement 2018 R. Müller (2018). Wyodrębnił on aż siedem perspektyw postrzegania project governance: funkcjonalną, procesową, instytucjonalną, strukturalną, interakcyjną, modelową i relacyjną. Z perspektywy naukowej systematyka taka wydaje się kompleksowa i pełna. Daje ona pole do szerokich interdyscyplinarnych badań, co może sprzyjać nadinterpretacji, tworzeniu pseudoteorii. $\mathrm{Z}$ perspektywy empirycznej nie wspomaga ona pogłębienia rozumienia i popularyzacji tego konstruktu wśród praktyków biznesu. W niemniejszym artykule postuluje się traktowanie project governance jako systemu tworzenia wartości, co znajduje odzwierciedlenie w literaturze przedmiotu (G1.4, s. 1310; G1.7, s. 104). Przedmiotowa wartość odnosi się przede wszystkim do $P 3$, które powinny indywidualnie oraz wspólnie tworzyć efekt portfela dla całej organizacji projektowej (Kozarkiewicz, 2012, s. 46-49), tj. zapewnić przede wszystkim sukces organizacji projektowej, w tym jej wzrost. Oznacza to dopasowanie strategii projektu do strategii organizacji realizującej projekt (G1.5).

W literaturze przedmiotu wskazuje się, że P4 governance jako system tworzenia wartości powinien realizować jednocześnie funkcje zarządczo-kontrolno-nadzorujące (G2.1; G3.5). Oznacza to, że system ten:

a) dostarcza podmiotom nadzorczym informacji na temat działania zespołów P3, umożliwia kontrolę, sposób ich realizacji czy osiągane rezultaty (performance),

b) zwiększa skuteczność i efektywność procesów zarządzania P4 i nadzoru nad nimi przez doskonalenie subprocesów, m.in.: planowania celów strategicznych, monitorowania i analizy działalności, w tym warunków ryzyka i niepewności, ewaluacji dokonań czy raportowania,

c) wspomaga zespoły $\mathrm{P} 3 \mathrm{w}$ pomiarze dokonań (performance measurement), tworząc system samokontroli.

Obserwując praktykę biznesową, można jednak odnieść wrażanie, że zadania drugie i trzecie są często marginalizowane. Dzieje się tak, ponieważ kadra kierownicza pełniąca rolę agenta (nawiązanie do teorii agencji) niejednokrotnie nie czuje bezpośrednich korzyści z funkcjonowania systemu governance. Stąd potrzeba dalszych badań w tym zakresie (G1.2, s. 30). Z drugiej strony podmioty nadzorujące (pryncypał) niejednokrotnie uważają, że governance nie jest systemem zarządzania operacyjnego, ale konstruktem wspomagającym zadania strategiczne, tj. dobór projektów do portfela, efektywne gospodarowanie zasobami organizacji (w tym przydzielanie ich do projektów), kontrolę realizacji przyjętych celów strategicznych. Tymczasem powinien on również przynosić korzyści zarządzającym na poziomie operacyjnym, tj. projektu/programu (G1.5), dostarczając dodatkowych informacji zarządczych. 
Realizacja przedstawionych zadań wymaga zabezpieczenia systemu od strony instytucjonalnej, co znajduje odzwierciedlenie $\mathrm{w}$ trendzie badawczym związanym Z przesuwaniem się środka ciężkości zainteresowania naukowców z projektu na portfel projektów czy PBO (G1.5; G3.3). Wydaje się, że działanie to jest uzasadnione z perspektywy konieczności zapewnienia pozytywnego efektu portfela. W tym kontekście wskazuje się kluczową rolę przede wszystkim project management office (PMO), ale również steering committee czy działu controllingu. Przeprowadzona analiza literatury wskazała, że naukowcy przede wszystkim eksplorują rolę PMO jako łącznika między projektem a PBO (G1.3). Znacznie mniej miejsca poświęcają innym działom/jednostkom wspomagającym. Tymczasem w wielu organizacjach zadania - szczególnie w zakresie raportowania ekonomicznego - są realizowane np. przez dział controllingu. Dlatego w przyszłości należałoby oczekiwać od naukowców skierowania większej uwagi na inne podmioty wspomagające system governance.

Przeprowadzona analiza literatury wskazuje również na wzrost zainteresowania problematyką P4 governance w kontekście interesariuszy zewnętrznych (G1.7; G2.1; G3.1; G3.2). Dlatego jako bardzo cenne należy uznać jednoznaczne wyodrębnienie z perspektywy więzi organizacyjnych dwóch kierunków badawczych, tj. projekt vs. organizacja projektowa (project governance as external to any specific project) oraz wykonawca (organizacja projektowa) vs. interesariusze zewnętrzni projektu (project governance as internal to a specific project) (G2.1, s. 1328). Niezależne prowadzenie tego typu studiów jest związane $\mathrm{z}$ różnicami występującymi w relacjach intraorganizacyjnych oraz interorganizacyjnych (Urbańska-Sojkin, 2018, s. 142-143) - rola, możliwości nadzorczo-kontrolne czy poziom współpracy (Mena, Humphries, Wilding, 2009, s. 762-784). Wśród najważniejszych interesariuszy zewnętrznych wymienia się klienta (zamawiającego), dostawców, podwykonawców, społeczeństwo, środki masowego przekazu, instytucje rządowe i samorządowe (G1.7, s. 106). W wyniku analizy zebranego materiału badawczego można wskazać na kilka niedostatków dotychczas prowadzonych studiów w tym obszarze. Przede wszystkim zbyt mało miejsca poświęca się problematyce governance $\mathrm{w}$ relacjach projekt vs. dostawca czy podwykonawca. Uwzględniając rosnącą rolę podwykonawstwa (Głodziński, 2017b, s. 20-21), istotne byłoby zbadanie czynników determinujących relacje i wpływających na budowę i wykorzystanie governance na tym poziomie zarządzania. Należałoby uwzględnić zarówno spełnianie funkcji nadzorczych, jak i wspomaganie zarządzania podwykonawcy, np. dostarczając mu dane dotyczące harmonogramu pracy czy charakteryzujące jakość i zakres wykonanych prac. Znamiennym jest, że większość publikacji koncentruje się na analizie wnętrza organizacji projektowej lub powiązaniach projektu lub PBO z kluczowym interesariuszem - zamawiającym. Przykładowo dokładnie omawiana jest rola steering committee w osiąganiu sukcesu przez projekt (Lechler, Cohen, 2009, s. 42-54; Turner, 2009, s. 368). Drugą istotną luką badawczą może być marginalizowanie trwałości systemu governance w odniesieniu do różnorodnych interesariuszy. Wewnątrz organizacji projektowej system ten zapewnia wspomaganie zarządzania (np. w odniesieniu do funkcji realizowanych przez zespoły projektowe) oraz nadzór nad ich działaniem. System governance powinien oddziaływać na wszystkie elementy tworzace portfel projektu. W tym przypadku można zaproponować tłumaczenie project governance jako ładu projektowego. Dotyczy on zarówno poziomu projektu, jak i programu czy portfela. Analizując relacje projektu $\mathrm{z}$ interesariuszami poza „organizacją matką”, należy zauważyć, że system governance ma charakter temporalny. Oznacza to, że został on zbudowany na potrzeby realizacji konkretnego przedsięwzięcia i po jego zakończeniu nie będzie wykorzystywany. W przypadku relacji projekt vs. zamawiający system governance jest definiowany w znacznej części przez klienta, który określa cele końcowe, cząstkowe, sposób raportowania itp. Reasumując, należy podkreślić, że w organizacji projektowej jednocześnie funkcjonuje wiele systemów project governance, intraorganizacyjny tworzący tad projektowy oraz intreorganizacyjne. który proponuje się nazywać systemem nadzoru nad projektem.

Kolejnym problemem badawczym podejmowanym przez naukowców i praktyków są analizy zastosowania różnorodnych teorii, najczęściej organizacji i zarządzania, ekonomicznych oraz behawioralnych. W tym przypadku można zauważyć występującą zgodność, że istnieją silne relacje project governance $\mathrm{z}$ corporate governance (G2.2; G3.1; G3.4; G3.5; G3.6). Dlatego wskazuje się na sześć zasadniczych teorii umożliwiających wyjaśnienie mechanizmów przedmiotowego systemu, tj.: agencji (agency), kosztów transakcyjnych (transaction cost), interesariuszy (stakekholder), właścicielskiej (shareholder), podwładności (stewardship), zasobowej (resource dependence). Analizując przedstawioną listę, nasuwa się pytanie o brak w tej grupie teorii sieci (network governance theory), która opisuje stałą i uporządkowaną współpracę między różnorodnymi podmiotami zaangażowanymi $\mathrm{w}$ tworzenie produktu projektowego. Zasady ich współpracy są definiowane stosownymi umowami. Zarządzanie oraz nadzór odnoszą się do procesu wytwarzania, $\mathrm{w}$ tym odpowiedniego reagowania na nieprzewidziane okoliczności w celu ochrony procesu wymiany między uczestnikami łańcucha dostaw (Jones i in., 1997, s. 914). Przedstawione podejście idealnie pasuje do środowiska projektowego i konieczności współpracy. Dlatego istnieje konieczność dalszych badań w tym zakresie, szczególnie w innych sekcjach gospodarki niż budownictwo, dla którego tego typu studia były już prowadzone (Pryke, 2005, s. 927-939; Głodziński, 2017b, s. 49-55). $\mathrm{W}$ tym miejscu można również zauważyć, że w analizowanych publikacjach wskazuje się, że podmioty budowlane są najczęściej wybieraną próbą badawczą $w$ badaniach nad P4 governance (G1.3). Szersza kwerenda literaturowa pokazuje jednak, że nie brak również studiów w ramach organizacji $\mathrm{z}$ takich sekcji gospodarki, jak informacja i telekomunikacja czy przetwórstwo przemysłowe (Müller, Lecoeuvre, 2014, s. 1346-1357).

Kolejnym istotnym trendem w zakresie badań nad governance $\mathrm{w}$ środowisku projektowym jest przesuwanie się zainteresowania badaczy $\mathrm{z}$ elementów twardych $\mathrm{w}$ kierunku analiz nad elementami miękkimi (G1.1; G1.7; 
G3.5). Wskazuje się, że szczególnego znaczenia nabierają one w przypadku dążenia organizacji do coraz wyższego poziomu dojrzałości projektowej (G1.4). Jest to wyrazem rosnącej projektyzacji działalności podmiotów gospodarczych oraz odzwierciedleniem potrzeby kreowania wartości dodanej przez system governance. W ramach studiów nad elementami miękkimi szczególne zainteresowanie kieruje się na zaufanie mocodawcy do pryncypała, uczciwość działania, elastyczność (G3.5) czy zwinność (G1.3; G1.6). Wskazuje się na potrzebę nie tylko zarządzania formalnego przez kierownika projektu, ale przede wszystkim kreowanie prawdziwych przywódców (leaderships). Trendy te są zgodne $\mathrm{z}$ aktualną modą i potrzebami biznesowymi, gdzie zwinne, hybrydowe czy ekstremalne zarządzanie projektem stanowią odpowiedź na nowe uwarunkowania otoczenia, w tym relacje projektu $\mathrm{z}$ jego interesariuszami zewnętrznymi.

Kwerenda badań z zastosowaniem systematycznej analizy literatury przedmiotu wskazuje również na aspekty metodologiczne. Podkreśla się, że w prowadzonych studiach nad governance dominuje podejście indukcyjne - od szczegółu do ogółu, najczęściej wykorzystywane metody badawcze to studium przypadku i badania ankietowe (G1.7). Wyniki te nie zaskakują. Tego typu narzędzia badawcze są charakterystyczne dla tematyki silnie osadzonej w praktyce. Nie oznacza to, że badacze pomijają studia o charakterze metodologicznym, w tym tworzenie ujęć modelowych. Są one domeną przede wszystkim instytutów zrzeszających praktyków (Project Management Institute, Association of Project Management itp.), choć nie tylko.

\section{Podsumowanie}

W drożenie systemu zarządczo-kontrolno-nadzorczego (governance) $\mathrm{w}$ organizacji projektowej prowadzić może do zwiększenia jej wartości, zarówno w ujęciu procesowym (wchodzenie na wyższy poziom dojrzałości projektowej), jak i produktowym (wzrost satysfakcji interesariuszy $\mathrm{z}$ rezultatów projektu / programu). W wyniku podjętych badań literaturowych wskazano kilka istotnych trendów (PB1): a) zróżnicowane definiowanie project governance, przede wszystkim z perspektywy przedmiotowej (odnoszenie tego konstruktu zarówno do projektu, jak i innych przedmiotów zarządzania - programu, portfela projektów, rzadziej organizacji projektowej),

b) coraz powszechniejsze traktowanie P4 governance jako systemu tworzenia wartości, który powinien realizować funkcje zarządczo-kontrolno-nadzorujące,

c) przesuwanie środka ciężkości zainteresowania naukowców z projektu na portfel projektów czy $\mathrm{PBO}$,

d) wzrost znaczenia systemów governance $\mathrm{w}$ zapewnianiu satysfakcji interesariuszy zewnętrznych,

e) adaptacja różnorodnych teorii organizacji i zarządzania, ekonomicznych czy behawioralnych do wyjaśniania związków między elementami strukturalnymi systemów governance,

f) prowadzenie wielu badań empirycznych nad rozwojem konstruktu governance organizacji projektowych w różnorodnych sekcjach gospodarki, początkowo przede wszystkim na podmiotach budowlanych, g) przesuwanie się osi zainteresowania naukowców i praktyków $\mathrm{z}$ elementów twardych w kierunku analiz nad elementami miękkimi badanego konstruktu.

W artykule zaproponowano kilka rozwiązań terminologicznych umożliwiających doprecyzowanie badanej tematyki oraz wyodrębnienie nowych obszarów eksploracji (PB2). Wśród najważniejszych propozycji jest wykorzystywanie oznaczeń P3 i P4 governance w odniesieniu do przedmiotowej problematyki. Umożliwiłoby to ograniczenie zastosowania terminu project governance jedynie do realizacji funkcji zarządczo-kontrolno-nadzorczych projektu oraz nazwy obszaru badawczego. W artykule zaproponowano, aby nazwę ład projektowy używać jedynie w odniesieniu do systemu funkcjonującego na potrzeby organizacji projektowej. W pozostałych przypadkach bardziej trafną nazwą dla systemów governance (np. definiujących relacje projekt vs zamawiający) byłaby nadzór nad projektem.

Odnosząc się do potrzeby eksploracji obszarów dotychczas mało rozpoznanych, podkreślono potrzebę głębszych analiz nad relacjami projekt vs. podwykonawca/dostawca. Postuluje się również prowadzenie poszerzonych studiów w zakresie adaptacji teorii sieci w środowisku projektowym.

Przeprowadzone badania inspirują do dalszych analiz. Z pewnością ład projektowy i koncepcja nadzoru nad projektem będą w przyszłości głębiej eksplorowane. Należy jednak zwrócić uwagę na ograniczenia w zakresie szerszej interpretacji uzyskanych wyników w ramach całej populacji. Przede wszystkim są one związane $\mathrm{z}$ wybraną metody badawczej (parasolowy przegląd literatury). Jej słabością jest brak bezpośredniego przeprowadzenia systematycznego przeglądu literatury przedmiotu, tj. wykorzystanie opracowań o charakterze wtórnym, być może obarczonych subiektywnością ich autorów. Wyodrębnione w niniejszym artykule teksty, choć publikowane $\mathrm{w}$ renomowanych czasopismach, mogą nie odzwierciedlać całości istniejącej wiedzy. Wpływ na to może mieć przyjęty ograniczony zestaw przeszukiwanych baz danych (Scopus, Google Schoolar) oraz wybór jedynie opracowań anglojęzycznych.

\section{dr hab. inż. Eryk Głodziński \\ Politechnika Warszawska \\ Wydział Inżynierii Produkcji \\ ORCID: 0001-9327-6046 \\ e-mail: eryk.glodzinski@pw.edu.pl}

\section{Przypisy}

1) Szerzej na temat tej metody m.in. w opracowaniach: G. Paré i inni (2015, s. 187), G. Paré, S. Kitsiou (2016, chapter 9), E. Aromatarisa (2015, s. 132-140).

2) Do tej grupy zakwalifikowano te publikacje, w których systematyczny przegląd literatury był główną metodą badawczą.

3) Na takie zastosowanie przeglądu parasolowego wskazują m.in. V. Smith i inni (2011, s. 1).

4) $\mathrm{Na}$ taki cel zastosowania tej metody badawczej wskazują m.in. L.A. Becker, A.D. Oxman (2008, s. 612).

5) Corporate governance jest różnie tłumaczony w polskojęzycznej literaturze przedmiotu, najczęściej jako: nadzór korporacyjny, 
ład korporacyjny, ład organizacyjny lub władanie korporacyjne. Analiza w zakresie dylematów tłumaczenia tego pojęcia na język polski przedstawiona została m.in. w opracowaniu J. Jeżaka (2013, s. 21-36). Według tego autora, najwłaściwszy jest termin ład korporacyjny, chociaż nie każdy podmiot ma charakter korporacyjny. Dlatego w dalszej części artykułu przyjęto tłumaczenie ład organizacyjny jako najwłaściwsze.

6) P3 oznacza project, program, portfolio. Oznaczenie to jest wykorzystywane w literaturze przedmiotu (np. APM, 2012).

\section{Bibliografia}

[1] Ahola T., Davies A. (2012), Insights for the Governance of Large Projects. Analysis of Organization Theory and Project Management: Administering Uncertainty in Norwegian Offshore Oil by Stinchcombe and Heimer, „International Journal of Managing Projects in Business", Vol. 5, No. 4, pp. 661-679.

[2] Ahola T., Ruuska I., Artto K., Kujala J. (2014), What is Project Governance and what Are its Origins? „International Journal of Project Management", Vol. 32, No. 8, pp. 1321-1332.

[3] Aluchna M., Postuła I. (2017), Kultura w badaniach nadzoru korporacyjnego. Uwarunkowania, wzajemne zależności i operacjonalizacja, „Acta Universitatis Lodziensis. Folia Oeconomica", Nr 6, s. 148-149.

[4] APM (2011), Directing Change. Guide to Governance of Project Management, Association for Project Management.

[5] APM (2012), APM Body of Knowledge, Sixth Edition, Association for Project Management, Buckinghamshire.

[6] Aromataris E., Fernandez R., Godfrey C.M., Holly C., Khalil H., Tungpunkom P. (2015), Summarizing Systematic Reviews: Methodological Development, Conduct and Reporting of an Umbrella Review Approach, ,International Journal of Evidence-Based Healthcare", Vol. 13, No. 3, pp. 132-140.

[7] Becker L.A., Oxman A.D. (2008), Overviews of Reviews, [in:] L. Higgins, S. Green (eds.), Cochrane Handbook for Systematic Reviews of Interventions, John Wiley \& Sons, West Sussex.

[8] Bekker M.C. (2014), Project Governance:"Schools of thought", "South African Journal of Economic and Management Sciences", Vol. 17, No. 1, pp. 22-32.

[9] Biesenthal C., Wilden R. (2014), Multi-level Project Governance: Trends and Opportunities, „International Journal of Project Management", Vol. 32, No. 8, pp. 1291-1308.

[10] Derakhshan R., Turner R., Mancini M. (2019), Project Governance and Stakeholders: A Literature Review, „International Journal of Project Management”, Vol. 37, No. 1, pp. 98-116.

[11] Freeman R.E., Reed D.L. (1983), Stockholders and Stakeholders: A New Perspective on Corporate Governance, „California Management Review”, Vol. 25, No. 3, pp. 88-106.

[12] Głodziński E. (2017a), Efektywność w zarządzaniu projektami. Wymiary - Koncepcje - Zależności, PWE, Warszawa.

[13] Głodziński E. (2017b), Efektywność w zarządzaniu projektami budowlanymi. Perspektywa wykonawcy, Oficyna Wydawnicza Politechniki Warszawskiej, Warszawa.

[14] Jeżak J. (2013), Corporate governance jako nowy obszar wiedzy i praktyki biznesowej, „Studia Ekonomiczne”, Nr 141, s. 21-36.

[15] Jones C., Hesterly W.S., Borgatti S.P. (1997), A General Theory of Network Governance: Exchange Conditions and Social Mechanisms, „Academy of Management Review”, Vol. 22, No. 4, pp. 911-945.
[16] Juchniewicz M. (2018), Projektyzacja - koncepcja, zakres, konsekwencje, „Studia i Prace Kolegium Zarządzania i Finansów", Nr 159, s. 43-60.

[17] Kozarkiewicz A. (2012), Zarzadzanie portfelami projektów, Wyd. Profesjonalne PWN, Warszawa.

[18] Lappi T., Karvonen T., Lwakatare L.E., Aaltonen K., Kuvaja P. (2018), Toward an Improved Understanding of Agile Project Governance: A Systematic Literature Review, „Project Management Journal", Vol. 49, No. 6, pp. 39-63.

[19] Lechler T.G., Cohen M. (2009), Exploring the Role of Steering Committees in Realizing Value from Project Management, „Project Management Journal”, Vol. 40, No. 1, pp. 42-54.

[20] Mena C., Humphries A., Wilding R. (2009), A Comparison of Inter-and Intra-organizational Relationships: Two Case Studies from UK Food and Drink Industry, ,International Journal of Physical Distribution \& Logistics Management", Vol. 39, No. 9, pp. 762-784.

[21] Müller R. (2012), Project governance, [in:] P.W. Morris, J.K. Pinto, J. Söderlund (eds.), The Oxford handbook of project management, Oxford University Press, Oxford, pp. 297-320.

[22] Müller R. (2018), Perspectives on Governance, Keynote speech, International Conference on Project MANagement - ProjMAN, September 2018, Lisbon.

[23] Müller R. (ed.), (2017), Governance and Governmentality for Projects Enablers, Practices, and Consequences, Taylor \& Francis, New York.

[24] Müller R., Lecoeuvre L. (2014), Operationalizing Governance Categories of Projects, „International Journal of Project Management", Vol. 32, No. 8, pp. 1346-1357.

[25] Müller R., Pemsel S., Shao J. (2014), Organizational Enablers for Governance and Governmentality of Projects: A Literature Review, „International Journal of Project Management", Vol. 32, No. 8, pp. 1309-1320.

[26] Musawir A., Abd-Karim S.B., Mohd Danuri M.S. (2016), Project Governance: Enabling Organizational Strategy, Conference 10th ASEAN Postgraduate Seminar.

[27] OECD (2015), G20/OECD Principles of Corporate Governance, September 2015.

[28] Paré G., Kitsiou S. (2016), Methods for Literature Reviews, [in:] F. Lau, C. Kuziemsky (eds.), Handbook of a Health Evaluation: An Evidence-based Approach, University of Victoria, chapter 9, https://www.ncbi.nlm.nih.gov/books/ NBK481583/, access date: 9.01.2019.

[29] Paré G., Trudel M.C., Jaana M., Kitsiou S. (2015), Synthesizing Information Systems Knowledge: A Typology of Literature Reviews, „Information \& Management”, Vol. 52, Iss. 2, pp. 183-199.

[30] PMI (2016), Governance of Portfolios, Programs, and Projects: A Practice Guide, Project Management Institute, Newtown Square.

[31] Pryke S. (2005), Towards a Social Network Theory of Project Governance, „Construction Management and Economics”, Vol. 23, No. 9, pp. 927-939.

[32] Pryke S., Pearson S. (2006), Project Governance: Case Studies on Financial Incentives, „Building Research \& Information", Vol. 34, No. 6, pp. 534-545.

[33] Samborski A. (2012), Governance w przedsiębiorstwie $w$ kontekście społecznej odpowiedzialności, „Przegląd Organizacji”, Nr 1, s. 14-17. 
[34] Shenhar A.J. (2001), Contingent Management in Temporary, Dynamic Organizations: The Comparative Analysis of Projects, „The Journal of High Technology Management Research", Vol. 12, No. 2, pp. 239-271.

[35] Shleifer A., Vishny R.W. (1997), A Survey of Corporate Governance, „The Journal of Finance”, Vol. 52, No. 2, pp. 737-783.

[36] Smith V., Devane D., Begley C.M., Clarke M. (2011), Methodology in Conducting a Systematic Review of Systematic Reviews of Healthcare Interventions, „BMC Medical Research Methodology", Vol. 11, pp. 1-6.

[37] Too E.G., Weaver P. (2014), The Management of Project Management. A Conceptual Framework for Project Governance, „International Journal of Project Management”, Vol. 32, No. 1, pp. 1382-1394.

[38] Tricker R.B., Tricker R.I. (2015), Corporate Governance: Principles, Policies, and Practices, Oxford University Press, USA.

[39] Trocki M. (2018), Project governance - kształtowanie ładu projektowego organizacji, „Studia i Prace Kolegium Zarządzania i Finansów", Nr 159, s. 9-23.

[40] Turner J.R. (2009), Handbook of Project-based Management. Leading Strategic Change in Organizations, Third Edition, McGraw-Hill, New York.

[41] Turner J.R., Müller R. (2003), On the Nature of the Project as a Temporary Organization, „International Journal of Project Management", Vol. 21, No. 1, pp. 1-8.

[42] Turner J.R., Müller R. (2017), The Governance of Organizational Project Management, [in:] S. Sankaran, R. Müller, N. Drouin (eds.), Cambridge Handbook of Organizational Project Management, Cambridge University Press, pp. 75-91.
[43] Urbanowska-Sojkin E. (2018), Uwarunkowania kreatywności w przedsiębiorstwach $w$ perspektywie strategicznej, „Organizacja i Kierowanie”, Nr 2(181), s. 135-146.

[44] Winch G.M. (2001), Governing the Project Process: A Conceptual Framework, „Construction Management and Economics", Vol. 19, No. 8, pp. 799-808.

\section{Project Governance - Essence, Current Research Directions and Development Perspectives}

\section{Summary}

Project governance constitutes a set of systems that support management and governance of projects, programmes, groups of projects, and project-based organisations. It should motivate managers to better work and support evaluation of $\mathrm{P} 4$ performance. The main objectives of the paper are to present the essence of project governance, describe crucial research trends and to propose new research areas. Seven streams of research have been distinguished based on the use of umbrella literature review. The crucial streams of research regard utilising project governance as a value creation system and to concentrate on soft components influencing management and governance. Further research related to relations between projects and their vendors or application of network theory in project environment is recommended by the Author.

\section{Keywords}

project governance, $\mathrm{P} 4$ governance, project supervision 